\title{
OVERLAP BETWEEN PINNIPED SUMMER DIET AND ARTISANAL FISHERY CATCHES IN URUGUAY
}

\author{
Diana Szteren ${ }^{1,2, *}$, Daniel E. Naya ${ }^{1,3}$ and Matías Arim ${ }^{3,4}$
}

\begin{abstract}
The similarity of the trophic ecology of Arctocephalus australis and Otaria flavescens in Uruguay was studied to help understand a possible trophic competition between the two species and its relation with artisanal fisheries. Dietary data for both pinnnipeds together with artisanal fisheries catch data were analyzed to estimate the overlap in prey species and sizes. Diet overlap was very high (Colwell and Futuyma overlap index, $\mathrm{C}=0.80$ ), with three fish species (Anchoa marinii, Cynoscion guatucupa, and Trichiurus lepturus) comprising more than $90 \%$ of the total number of individuals consumed by both species. In addition, the length of these three fish prey taken by fur seals and sea lions was similar, suggesting a large overlap not only in species but also in the size of prey ingested. The main difference between the two pinniped diets was that O. flavescens showed a more diverse diet than A. australis. Concerning pinnipedfisheries interactions, a low level of overlap was observed between the diet of each pinniped and artisanal fisheries catches $(C=0.22$ for $O$. flavescens, and $C=0.09$ for $A$. australis). Possibly, sea lion diet is broader than artisanal fisheries catches. Length comparisons for $C$. guatucupa, the only species well represented in both pinniped species diet and fisheries catches, indicated that individuals taken by the latter were larger than those consumed by the pinnipeds. However, the use of different age classes of the same resource, at different times or spatial locations do not imply less intensity of the interaction.
\end{abstract}

Resumen - Se estudió la similitud en la ecología trófica entre Artocephalus australis y Otaria flavescens en Uruguay, para comprender la posible competencia trófica entre ellas y su relación con la pesca artesanal. Para ello, se analizaron datos de dieta de ambos pinnnipedos junto con datos de capturas de la pesca artesanal, para estimar el solapamiento de especies y tamaños de presas. El solapamiento de dieta entre $O$. flavescens y A. australis fue muy alto (índice de solapamiento de Colwell and Futuyma, $\mathrm{C}=0.80$ ), y tres especies (Anchoa marinii, Cynoscion guatucupa, and Trichurus lepturus) comprendieron mas del $90 \%$ del total de presas consumidas. Además, la talla de estas tres especies fue similar para ambos Pinnipedos, por lo que se sostiene que existe un gran solapamiento, no solo de especies sino también de las tallas de presas ingeridas. La principal diferencia entre ambas dietas fue que $O$. flavescens presentó una dieta más diversa que $A$. australis. En referencia a las interacciones entre Pinnipedos y pesquerías, se observó bajo solapamiento entre la dieta de cada especie y las capturas de la pesca artesanal $(\mathrm{C}=0.22$ para O. flavescens, y $\mathrm{C}=0.09$ para A. australis). Posiblemente, la dieta de O. flavescens sea más amplia que las capturas pesqueras. Las comparaciones de tallas para C. guatucupa, la única especie bien representada en la dieta de ambos Pinnípedos y en las capturas pesqueras, indicó que los peces capturados eran mayores que las consumidas por los lobos marinos. Sin embargo, el uso de diferentes clases de edad de un mismo recurso, en diferente escala espacio temporal, no necesariamente implica menor intensidad de la interacción.

Keywords: Otaria flavescens, Arctocephalus australis, diet, artisanal fishery, dietary overlap.

\section{Introduction}

The extent of trophic interactions between marine mammals and fisheries is an increasingly important issue for conservation and fisheries management, and a cause of debate in different ambits. Conflicts between pinnipeds and fisheries occur worldwide, varying in extent and impact according to the pinniped species involved, the fishing gear used, the geographical area and season. Passive gear and the increase of fishing activities in coastal areas have caused an increase in the interactions between fisheries and seals worldwide (Harwood, 1987). In this sense, interaction with fishing operations has been recorded for 36 of the 45 pinniped species and subspecies currently known (Wickens, 1995). In South America, there is some information about this topic for all the countries which share the distribution of southern sea lions, such as in Argentina (Crespo et al., 1995; Fazio et al., 20005), Chile (Oporto et al., 1991, Rodriguez and Stotz, 2002 ${ }^{6}$, Hückstädt and Antezana,

\footnotetext{
${ }^{1}$ Universidad de la República, Facultad de Ciencias, Sección Zoología Vertebrados. Iguá 4225 Montevideo, 11400 Uruguay.

${ }^{2}$ Universidad de la República, Facultad de Ciencias, Departamento de Ecología. Iguá 4225 Montevideo, 11400 Uruguay.

${ }^{3}$ Pontificia Universidad Católica de Chile, Center for Advanced Studies in Ecology \& Biodiversity. Alameda 340 CP 6513677, Casilla 114 -D Santiago, Chile.

${ }^{4}$ Centro de Investigaciones en Ciencias Marinas (CICIMAR)-IPN. Av. Instituto Politécnico Nacional s/n. Col. Playa Palo de Santa Rita. La Paz, B.C.S. 23096 Mexico.

*Corresponding author - D. Szteren. CICIMAR- IPN. Fax: +52 (612)12 25322. E-mail: dszteren@ipn.mx, diana@fcien.edu.uy.

${ }^{5}$ Fazio, A., Palmeiro, A., Mendez, M., Botta, S. and Bordino, P. (2000). Interacción entre lobos marinos de un pelo Otaria flavescens y la pesquería artesanal del Cabo San Antonio, Buenos Aires, Argentina. Page 44 in Abstracts, $9^{a}$ Reunión de Trabajo de Especialistas en Mamíferos Acuáticos de América del Sur y $3^{\circ}$ Congreso de la SOLAMAC, 30 October - 3 November 2000, Buenos Aires, Argentina.

${ }^{6}$ Rodríguez, A.L. and Stotz, W. (2002). Descripción de la interacción del lobo marino común, Otaria flavescens (Shaw, 1800) en la actividad de los pescadores artesanales de las caletas de Coquimbo y Peñuelas, IV Región, Chile. Page 46 in Abstracts, $10^{a}$ Reunión de Trabajo de Especialistas en Mamíferos Acuáticos de América del Sur y 4 Congreso de la SOLAMAC, 14-19 October 2002, Valdivia, Chile.
} 
2003), Peru (Arias Schreiber, 1993), and Brazil (Carvalho et al., 19967; Ott et al., 19968; Soto et al., 2000).

Two types of interactions between marine mammals and fisheries may be studied. Operational interactions, which include damage to fishing gear or catches, disturbance to the fishing activity and marine mammal incidental catch, and biological interactions which involves predation or competition for resources between both predators (Wickens, 1995). In Uruguay, only one study focused on operational interactions between southern sea lions and artisanal fisheries quantifying damages caused by the animals to the fishing catches (Szteren and Páez, 2002). However, no studies have considered ecological interactions.

Two otariid species breed in some coastal islands off Uruguay, the South American fur seal (Arctocephalus australis) and the southern sea lion (Otaria flavescens). The Uruguayan fur seal population is the largest of this species worldwide, reaching about 300000 individuals (Páez, 2000). On the other hand, the population of O. flavescens was estimated in approximately 12000 animals in 1996, with a decreasing trend of 5-7\% yearly (Páez, 1996 $\left.{ }^{10}\right)$. One of the proposed causes of this population decline is the illegal killing by artisanal fishermen (Vaz-Ferreira et al., $\left.1994^{11}\right)$. Unlike the off-shelf foraging of A. australis, southern sea lions forage in coastal waters and frequently interact with artisanal fishing activities (Vaz-Ferreira, 1976). Another possible cause, not previously mentioned, could be the interaction between both pinniped species for trophic resources.

Competition between species implies a reduction in some population attributes, such as growth, survival or fecundity rates, with the condition of a limited resources supply (Begon et al., 1996). The relationship between population rates and other biological variables like species abundance, resources availability and potential competitors is not straightforward. The use of dietary overlap indexes gives information on the similarity of the trophic biology of the species involved. Therefore, these indexes are a valuable approach to assess the existence of potential interactions among species through exploitative competition. The aim of the present study is to analyse the overlap in prey species and sizes between both pinniped species, and between each species and artisanal fishery catches in Uruguay.

\section{Methods}

A total of 137 scats of $A$. australis and 57 of $O$. flavescens were collected in January 1998, at 'Isla de Lobos' rookery $\left(35^{\circ} 01^{\prime} 50^{\prime \prime} \mathrm{S}-54^{\circ} 53^{\prime} 00^{\prime \prime} \mathrm{W}\right)$ on the Atlantic coast of Uruguay. The methodology concerning scat collection is described in detail in Naya et al. (2000; 2002). Sagittal otoliths were recovered and then identified using reference material and published identification guides. Percent minimum number of individuals (\%MN) was calculated as:

$$
\% M N=\frac{n i}{\text { ntotal }} * 100
$$

where, $n i$ is the number of individuals of an item, and ntotal is the total number of individuals (Naya et al., 2000). This index measures the minimum number of individual prey taxa, and it uses the maximum count of otoliths (right or left) or cephalopod beaks (upper or lower) (Lowry et al., 1990). To estimate prey size only otoliths with low or no erosion were measured, using a correction factor of $15 \%$ to otoliths with little erosion. Fish lengths were estimated from regressions (Naya et al., 2002).

During the same month, a quantification of artisanal fisheries catch was recorded directly onboard fishing boats at three localities on the Uruguayan coast (Szteren and Páez, 2002). These three localities, named 'Piriápolis', 'La Paloma' and 'Cabo Polonio', are situated within a maximum distance of 100km from 'Isla de Lobos' (Figure 1). Data were collected during 14 trips onboard artisanal fishing boats: eight on bottom gillneters and six on longliners. These data were pooled for the analyses in this study. Fishing boats are between 4 and $9 \mathrm{~m}$ long, with outboard engines and operate within 5 to 7 nautical miles from the coast. During the fishing trips observers recorded each fish species caught, and the total weight per species. Prey diversity was analyzed by a rarefaction procedure (Heck et al., 1975; Naya et al., 2002). This method allows comparing

\footnotetext{
${ }^{7}$ Carvalho, R.V., Silva, K.G. and Messias, L.T. (1996). Os pinípedes e a pesca no litoral do Rio Grande do Sul, Brasil. Abstract. Addendum, in Abstracts $7^{\text {a }}$ Reunión de Trabajo de Especialistas en Mamíferos Acuáticos de América del Sur. (SOLAMAC), 22-25 October 1996, Viña del Mar, Chile.

${ }^{8}$ Ott, P.H., Moreno, I.B., Danilewicz, D. and Olivera, L.R. (1996). Leões marinhos (Otaria flavescens) e a pesca costeira no sul do Brasil: uma análise preliminar das competições e conflitos. Page 62 in Abstracts $7^{a}$ Reunión de Trabajo de Especialistas en Mamíferos Acuáticos de América del Sur. SOLAMAC. 22-25 October 1996, Viña del Mar, Chile.

${ }^{9}$ Soto, J.M., Souza Filho, M.B. and Mincarone, M.M. (2000). Interação do leão-marinho, Otaria flavescens (Shaw, 1800), com a pesca de emalhe na costa do Rio Grande do Sul, Brasil. Pages 733-735 in Abstracts Anais da XIII Semana Nacional de Oceanografia. 29 October03 November 2000, Itajaí, SC, Brasil.

${ }^{10}$ Páez, E. (1996). Simulaciones estocásticas en la población de Otaria flavescens en Uruguay. Page 116 in Abstracts, $7^{\text {a }}$ Reunión de Trabajo de Especialistas en Mamíferos Acuáticos de América del Sur, 22-25 October 1996, Viña del Mar, Chile.

${ }^{11}$ Vaz-Ferreira R., Páez, E., Ponce de León, A., Bianco, J., Rios, C. and Stagi, A. (1994). Relaciones entre el león marino de Sudamérica, Otaria flavescens y el lobo de dos pelos de Sudamérica, Arctocephalus australis en Uruguay. Page 11 in Abstracts, Primer Encuentro Nacional sobre Fauna Acuática. Sociedad Zoológica del Uruguay and Instituto Nacional de Pesca. October, 1994, Montevideo, Uruguay.
} 
different samples of prey species found in several predators, because it calculates the expected richness of species in each sample if all samples were of a standard size. This is the only diversity measure sensitive to rare species and unbiased by sample size (Magurran, 1988). The overlap between pinniped diets and each of the species diet with fisheries catches was calculated by the Colwell and Futuyma (1971) index,

$$
C=1-1 / 2 * \sum_{j=1}^{n}\left|p_{1 j}-p_{2 j}\right|
$$

where $\mathrm{p}_{1 j}$ and $\mathrm{p}_{2 j}$ are the proportions of the $j$ th prey item in pinnipeds diet or in the fishery catch. Overlap was calculated from prey numeric composition, discarding unidentified prey in the estimation.

Differences in prey mean lengths between pinnipeds and between each species and fishery catches was tested. The homogeneity of variances was verified through Levene test. This test is powerful for population distributions and is less sensitive to normality in the data (Sahai and Ageel, 2000), minimizing the necessity to transform the data or using a low power non-parametric test. According to the Levene test the null hypothesis (homogeneity of variances) could not be rejected and the Student $\mathrm{t}$-test was applied.

\section{Results}

Fur seal-sea lion dietary overlap

A total of eight prey taxa were found in the scats of each pinniped species. However, despite the same value for the observed richness, the rarefaction curves showed that the diet diversity was greater in O. flavescens than in A. australis (Figure 2).

Dietary overlap between the two pinniped species was high, reaching a Colwell and Futuyma overlap index of 0.80. For both otariid species, the anchovy (Anchoa marinii), the weakfish (Cynoscion guatucupa) and the cutlassfish (Trichiurus lepturus) were the most consumed fish species (Table 1, Figure 3). Cephalopods were an important prey item for $A$. australis but not for $O$. flavescens. In addition, the estimated length of these prey (Table 2) did not differ between both otariid species (A. marinii: $\mathrm{t}_{185}=1.23, \mathrm{p}=0.22 ;$ C. guatucupa: $\mathrm{t}_{13}=1.94, \mathrm{p}=0.07$; T. lepturus: $\left.\mathrm{t}_{21}=1.79, \mathrm{p}=0.09\right)$.

\section{Pinnipeds-fishery overlap}

The Brazilian codling (Urophycis brasiliensis) constituted the greatest proportion of artisanal fisheries catches; however, it was only found in scats of $O$. flavescens in a low proportion (Table 1, Figure 3). Other important fish in the catches were C. guatucupa and the narrownose smothhound (Mustelus schmitti). Overlap between these catches and pinniped diets at 'Isla de Lobos' was low for both species, being higher for $O$. flavescens $(C=0.28)$ than for $A$. australis $(C=0.09)$ (Figure 3$)$. Comparison of fish lengths between pinniped species and fisheries was done only for C. guatucupa (Table 2) because it was the only species taken by both pinniped species and fisheries. Individuals caught by fisheries were larger ( $>3$ years) than those consumed by the pinnipeds (1-2 years) $\left(\mathrm{t}_{85}=\right.$ 8.27, $\mathrm{p}<0.001$ for $A$. australis, and $\mathrm{t}_{90}=9.21, \mathrm{p}<0.001$ for $O$. flavescens) (ages according to Ehrhardt et al., 1977).

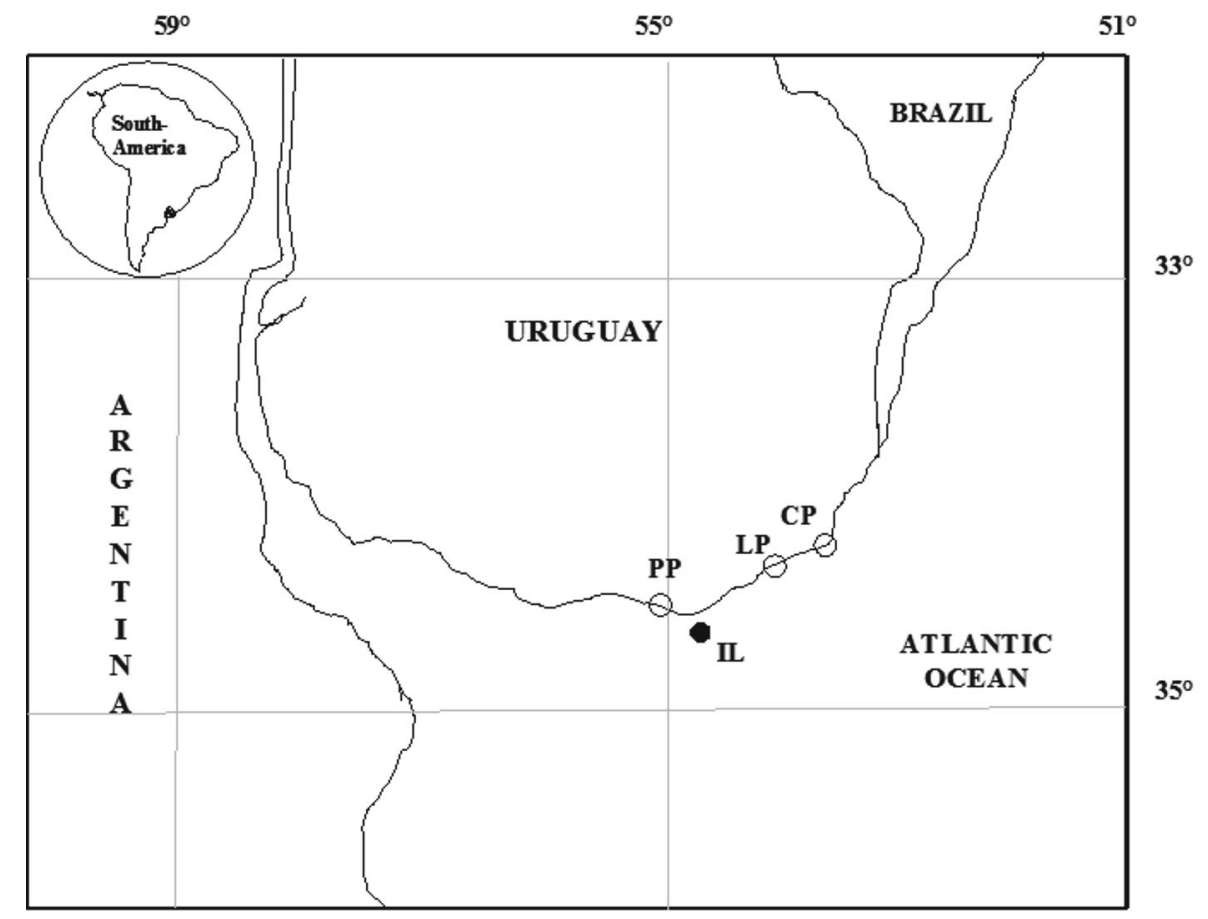

Figure 1. Study area, showing the location of the seal colony 'Isla de Lobos' (IL), and the three fishing localities: Piriápolis (PP), La Paloma (LP), and Cabo Polonio (CP). 


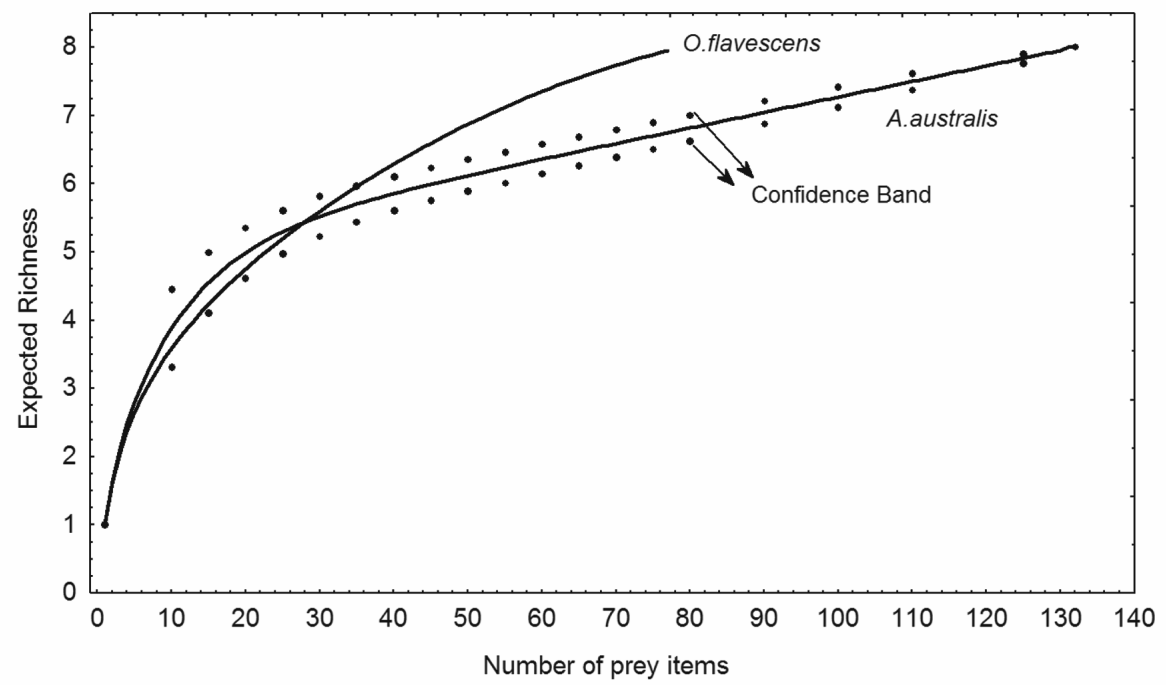

Figure 2. Rarefaction curves of A. australis and O. flavescens diets, at 'Isla de Lobos', Uruguay. Dot lines represent $95 \%$ confidence intervals for $A$. australis.

Table 1. Percent number of individuals (\%NI) of each item consumed by A. australis, O. flavescens and number of individuals caught by artisanal fisheries.

\begin{tabular}{lccc}
\hline \hline PREY ITEMS & $\%$ NI & \%NI & NI FISHERIES \\
& A. australis & O. flavescens & $(1371 \mathrm{~kg})$ \\
\hline \hline Cynoscion guatucupa & 8.33 & 22.78 & 28.42 \\
Engraulis anchoita & 6.82 & 2.53 & 0 \\
Anchoa marinii & 56.06 & 56.96 & 0 \\
Trichiurus lepturus & 14.39 & 10.12 & 0 \\
Urophycis brasiliensis & 0 & 1.27 & 36.75 \\
Micropogonias furnieri & 0.76 & 1.27 & 9.09 \\
Mustelus schmitii & 0 & 0 & 22.54 \\
Conger japonicus & 0 & 2.53 & 1.86 \\
Trachurus lathami & 0.76 & 0 & 0 \\
Merluccius hubbsi & 0.76 & 0 & 0 \\
Umbrina canosai & 0 & 0 & 0.35 \\
Parona signata & 0 & 0 & 0.87 \\
Cephalopods & 12.12 & 2.53 & 0 \\
\hline \hline $\mathrm{n}$ & 137 & 57 & 36 \\
No. ind. & 132 & 80 & 1718 \\
\hline \hline
\end{tabular}

(n) number of scats analysed or number of fishing trips observed, (No. ind.) number of individuals.

Table 2. Mean length ( $\mathrm{L}$, in mm), standard deviation (sd), and number of individuals (n) measured for the three main fish prey of $A$. australis and O. flavescens at "Isla de Lobos", and caught by artisanal fisheries.

\begin{tabular}{lrcccccccc}
\hline \hline & \multicolumn{3}{c}{ A. australis } & \multicolumn{3}{c}{ O. flavescens } & \multicolumn{3}{c}{ FisHERIES } \\
& $\mathrm{L}$ & $\mathrm{sd}$ & $\mathrm{n}$ & $\mathrm{L}$ & $\mathrm{sd}$ & $\mathrm{n}$ & $\mathrm{L}$ & $\mathrm{sd}$ & $\mathrm{n}$ \\
\hline \hline C. guatucupa & 204.6 & 34.5 & 5 & 242.5 & 46.3 & 10 & 394.8 & 50.6 & 82 \\
A. marinii & 78.7 & 8.3 & 112 & 80.2 & 7.7 & 75 & - & - & - \\
T. lepturus & 681.7 & 97.9 & 18 & 761.7 & 14.8 & 5 & - & - & - \\
\hline \hline
\end{tabular}




\section{Discussion}

The diet of $A$. australis and $O$. flavescens was dominated by a few prey species, in agreement with other otariid dietary studies (e.g. Majluf, 1989; Goldsworthy et al., 1997; Dellinger and Trillmich, 1999; Koen Alonso et al., 2000). The greatest difference between both otariids diet was that $O$. flavescens presented a slightly more diverse diet than $A$. australis. The ability of $O$. flavescens to exploit a wide range of prey has been previously mentioned for Argentina (Crespo et al., 1995; Koen Alonso et al., 2000), and Chile (GeorgeNascimento et al., 1985), the same being true for other sea lion species in other geographic areas (e.g. Lowry et al., 1990 for Zalophus californianus; Lalas, 1997 for Phocarctos hookeri). Camacho Rios (2004) also compared the diet of a sea lion (Z. californianus) and a fur seal (Arctocephalus townsendi) in sympatry, and concluded that the sea lion's diet was richer and more diverse than that of fur seals.

Although there is considerable information about otariid diets, there are few publications comparing the diet of otariid species in sympatry. Among the studies that have been conducted, the observed relationship between diet overlap and foraging area distribution has shown contrasting results. For example, Dellinger and Trillmich (1999) also used the Colwell and Futuyma's index to analyze the overlap between Z. californianus and Arctocephalus galapagoensis, and concluded that they both use the same foraging areas but have a very low diet overlap. Apparently both species avoided competition by feeding at different times of the day. Using radio-transmitters and scat analysis, Antonelis et al. (1990) studied the foraging behaviour and diet of Callorhinus ursinus and Z. californianus in California. Both pinnipeds fed on similar prey but used different foraging areas (Antonelis et al., 1990). Arctocephalus gazella and A. tropicalis had similar diets and foraging areas at Macquarie island (Goldsworthy et al., 1997). Camacho Rios (2004) analysed scats from Z. californianus and A. townsendi in Mexico, and found that the dietary overlap was minimal. An ecologic segregation in the use of habitat was proposed, where A. townsendi would feed farther from the coast than Z. californianus. For the pinnipeds studied herein, previous reports also suggest a spatial segregation with $A$. australis foraging mainly outside the continental shelf and $O$. flavescens foraging near the coast, both using similar prey species (Vaz-Ferreira, 1976).

A high overlap index can be evidence for or against the existence of competition, because despite competition may be operating, exclusion or displacement may be incomplete or impossible (Colwell and Futuyma, 1971). The extensive diet overlap between the two otariid species at 'Isla de Lobos' rookery indicated that the segregation of foraging areas was not associated with a marked resource differentiation. According to Antonelis et al. (1990), the greater overlap occurs when prey are most abundant, and the maximum segregation when prey are scarce. If this is true, in our example the low overlap between $A$. australis and $O$. flavescens, and the high overlap between the latter and artisanal fisheries, would be reflecting scarcity of resources in our study time.

Since the diets were analyzed during summer when both pinniped species are mainly restricted to land, the observed overlap could be overestimated as a result of an overrepresentation of prey caught close to 'Isla de Lobos', similarly to what was observed for New Zealand fur seals (see Fea and Harcourt, 1997). The analysis developed in this study is based on information taken in one month (January 1998), which constrains the generality of the obtained results. Nevertheless, we assume high diet diversity in this month (as found by Naya et al. (2002) for A. australis, and Camacho Rios (2004) for Z. californianus). In the case of $A$. australis, the breeding season is over by early January, so all age classes may be feeding at sea. As a result, the scats likely represent the first post-breeding foraging trips. Sea lions are in their breeding season so

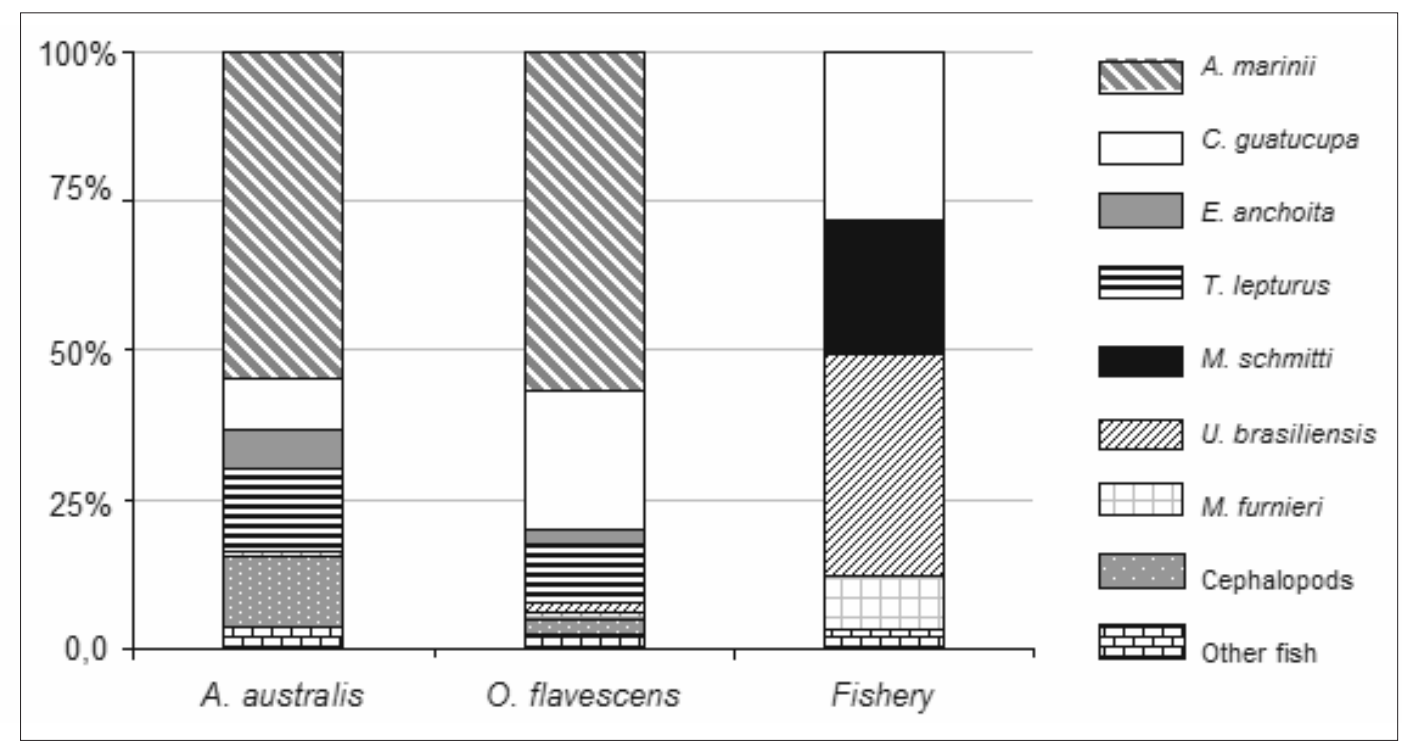

Figure 3. Consumption by A. australis and O. flavescens (in percentage number of individuals) of each prey species at 'Isla de Lobos', and artisanal fisheries catches. 
the majority of the age classes are restricted to land. Scats would represent short foraging trips near the island for lactating females, normal diet of juveniles, or a rich diet prior to the fasting period in males.

The overlap between the diet of both pinniped species and fisheries catches seems low, and only C. guatucupa was an important resource for the three (Figure 3). However, the size classes of the prey species consumed by pinnipeds were smaller than those caught by the artisanal fisheries. This non-overlapping consumption is in agreement with previous findings in other geographic areas. For example, in the Falklands islands, Thompson et al. (1998) found no overlap between fish items in O. flavescens diet and the landed catch. Sea lions were taking smaller sizes than the fishery. The same was reported by Swartzman and Haar (1983) between Callorhinus ursinus and commercial fisheries at the Bering sea. In Patagonia (Argentina) commercial as well as non-commercial fish sizes were consumed by $O$. flavescens (Crespo et al., 1997; Koen Alonso et al., 2000). However, it should be noted that the consumption of different fish size-classes by pinnipeds and fisheries should not be equated with a lower intensity of competition (Harwood, 1987; Koen Alonso et al., 2000). This is because the existence and extent of competition will depend on the effect of the fish removal by otariids and fisheries on fish population dynamics (Yodzis, 2001). The use of the same resource of different age classes or at different times or spatial locations does not necessarily mitigate the intensity of the interaction (Harwood, 1987). It is important to highlight that artisanal fisheries are only catching a range of fish species and sizes, depending on the mesh size and type. Thus, our results help to confirm that the diet of sea lions can be broader than artisanal fisheries catches, allowing to a better understanding of the extent of the interaction between this fishery and pinnipeds.

The population of $O$. flavescens in Uruguay is declining; however, the causes are unknown. They could be related to the diet as has been found for Steller sea lions. For that species, Merrick et al. (1997) found that the lower the diet diversity, the greater the rates of decline in different populations in the Gulf of Alaska and the Aleutian Islands. In California (U.S.A.) sea lions exhibited more diverse diets during adverse environmental conditions (e.g. El Niño), because the preferred prey would be absent or less available to the animals (Lowry et al., 1991). The greater the prey diversity in sea lions diet, the lower the interaction with fisheries might be, if these prey species have commercial importance.

Collection of fur seal and sea lion scats in Uruguay show some difficulties, particularly for the latter. First, the risk of high pup mortality due to crushing by adults during herd disturbances restricts the number of faeces that can be assembled. Second, the population decline of $O$. flavescens implies that, in the last years fewer areas on the rookery were occupied only by this species. In addition, most of these areas are of difficult access to humans, making it a challenge to find zones where scats can be collected with confidence about pinniped species identity.

Although limited in time, the present research represents the first attempt to understand seal and sea lion-fisheries resource interaction on the Uruguayan coast. Further studies should investigate the dynamic of this and other fisheries-interactions over time and space to better understand the potential interactions among pinnipeds and fisheries.

\section{Acknowledgements}

We wish to thank A. Canavero and N. Gutiérrez for their help in field work at Isla de Lobos, and to many fishermen who allowed D.S. onboard their boats. Special thanks are extended to F. Trillmich for his comments on an earlier version of the manuscript, and to Eduardo Secchi and two anonymous referees for their corrections and valuable comments. Nélio Barros provided suggestions to improve the English. This work was funded by Programa de Maestría en Manejo de Vida Silvestre, Universidad Nacional de Córdoba, Argentina (to D.S.), Programa de Desarrollo de las Ciencias Básicas, Uruguay (to D.E.N.), Comisión Sectorial de Investigación Científica, Uruguay, and Center for Advanced Studies in Ecology and Biodiveristy, CASEB, Chile (to M.A).

\section{References}

Antonelis, G.A., Stewart, B.S. and Perryman, W.F. (1990) Foraging characteristics of female northern fur seals (Callorhinus ursinus) and California sea lions (Zalophus californianus). Canadian Journal of Zoology, 68: 150-158.

Arias Schreiber, M. (1993) Interacciones entre lobos marinos Otaria byronia y la pesquería artesanal en el puerto San Juan de Marcona, Perú. Tesis para optar al Título de Biólogo. Universidad Nacional Agraria La Molina. Lima, Perú. 29pp.

Begon, M., Mortimer, M. and Thompson, D. (1996) Population Ecology. A unified study of animals and plants. Third Edition. Blackwell Science, Cambridge. 247pp.

Camacho Rios, F.J. (2004) Estructura alimentaria y posición trófica de dos especies de Otaridos Zalophus californianus y Arctocephalus townsendi, en las Islas San Benito, B.C. Mexico. Tesis de Maestría en Manejo de Recursos Marinos. CICIMAR - Instituto Politécnico Nacional. La Paz, B.C.S., México. 53pp.

Colwell, R.K. and Futuyma, D.J. (1971) On the measurement of niche breath and overlap. Ecology 52: 567-576.

Crespo, E.A., Pedraza, S.N., Dans, S.L., Koen Alonso, M., Reyes, L.M., García, N.A. and Coscarella, M. (1997) Direct and indirect effects of the high seas fisheries on the marine mammal populations in the northern and central patagonian coast. Journal of the Northwest Atlantic Fishery Science 22: 189-207.

Dellinger, T. and Trillmich, F. (1988) Estimating diet composition from scat analysis in otariid seals (Otariidae): Is it reliable? Canadian Journal of Zoology 66: 1865-1870. 
Ehrhardt, N.M., Arena, G.J., Varela, Z.M., Abella, A.J., Rios, C.A. and De Moratorio, N.B. (1977) Evaluación preliminar de los recursos demersales en el área común de pesca ArgentinoUruguaya 1975-1976. Instituto Nacional de Pesca. Informe Técnico No.11. 176pp.

Fea, N. and Harcourt, R. (1997) Assessing the use of fecal and regurgitate analysis as a means of determining the diet of New Zealand Fur Seals. Pages 143-150 in Hindell, M. and Kemper, C. (Eds) Marine Mammal Research in the Southern Hemisphere. Volume 1: Status, Ecology and Medicine, Surrey Beatty \& Sons, Australia.

George-Nacimento, M., Bustamante, R. and Oyarzun, C. (1985) Feeding ecology of the South American sea lion Otaria flavescens: food contents and food electivity. Marine Ecology Progress Series 21: 135-143.

Goldsworthy, S.D., Hindell, M.A. and Crowly, H.M. (1997) Diet and diving behaviour of sympatric fur seals Arctocephalus gazella and A. tropicalis at Macquerie Island. Pages 151-163 in Hindell M. and Kemper, C. (Eds) Marine Mammal Research in the Southern Hemisphere. Volume 1: Status, Ecology and Medicine. Surrey Beatty \& Sons, Australia.

Harwood, J. (1987) Competition between seals and fisheries. Scientific Progress, Oxford, 71: 429-437.

Hückstädt, L. and Antezana, T. (2003) Behavior of the southern sea lion (Otaria flavescens) and consumption of the catch during purse-seining for jack mackerel (Trachurus symmetricus) off central Chile. ICES Journal of Marine Science 60: 1003-1011

Heck K.L., Van Belle Jr, G. and Simberloff, D. (1975) Explicit calculation of the rarefaction diversity measurement and the determination of sufficient sample size. Ecology 56: 1459-1461.

Koen Alonso, M., Crespo, E.A., Pedraza, S.N., García, N.A. and Coscarella, M.A. (2000) Food habits of the South American sea Lion, Otaria flavescens, of Patagonia, Argentina. Fishery Bulletin 98: 250-263.

Krebs, C. (1989) Ecological Methodology. Harper \& Row Publishers, Inc. New York. 656pp.

Lalas, C. (1997) Prey of Hooker's Sea Lions Phocarctos hookeri based at Otago Peninsula New Zealand. Pages 130-136 in Hindell, M. and Kemper, C. (Eds) Marine Mammal Research in the Southern Hemisphere. Volume 1: Status, Ecology and Medicine. Surrey Beatty \& Sons, Australia.

Lowry, M.S., Oliver, C.W., Macky, C. and Wexler, J.B. (1990) Food habits of California sea lions Zalophus californianus at San Clemente Island, California, 1981-1986. Fishery Bulletin 88: 509-521.
Magurram, A.E. (1988) Ecological Diversity and its Measurement. Princeton University Press. Princeton.

Majluf, P (1989) Reproductive ecology of South American fur seals in Peru. Pages 332-343 in Pauly, D., Muck, P., Mendo, J. and Tsukayama, I. (Eds) The Peruvian upwelling ecosystem: dynamics and interactions. ICLARM Conference Proceedings. Instituto del Mar del Perú (IMARPE). Callao, Perú.

Naya D.E., Arim, M. and Vargas, R. (2000) Análisis preliminar de la dieta del león marino del sur (Otaria flavescens) en Isla de Lobos, Uruguay. Boletín de la Sociedad Zoológica del Uruguay 12: 14-21.

Naya D.E., Arim, M. and Vargas, R. (2002) Diet of the South American fur seal, Arctocephalus australis in Isla de Lobos, Uruguay. Marine Mammal Science 18: 734-745.

Oporto, J., Mercado, C. and Brieva, L. (1991) Conflicting interactions between coastal fisheries and pinnipeds in southern Chile. Report on the Benguela Ecology Programme workshop on seal-fishery biological interactions, University of Cape Town. Working Paper BEP/SW91/ R8. 21pp.

Páez, E. (2000) Utilización del bootstrap y análisis de poder en estimaciones de abundancia de cachorros de Arctocephalus australis. Pages 55-74 in Reid, M. and Amestoy, F. (Eds) Sinopsis de la biología y ecología de las poblaciones de lobos finos y leones marinos del Uruguay. Pautas para su manejo y administración. Parte II. Evaluación de los recursos. INAPE. Montevideo.

Sahai and Ageel (2000) The Analysis of Variance. Bikhauser, Berlin. Germany.

Szteren, D. and Páez, E. (2002) Predation by southern sea lions (Otaria flavescens) on artisanal fishing catches in Uruguay. Marine and Freshwater Research 53: 1161-1167.

Swartzman, G.L. and Haar, R.T. (1983) Interactions between fur sea populations and fisheries in the Bering sea. Fishery Bulletin 81: 121-132.

Thompson D., Duck, C.D., McConnell, B.J. and Garrett, J. (1998) Foraging behaviour and diet of lactating female southern sea lions (Otaria flavescens) in the Falkland Islands. Journal of Zoology, London 246: 135-146.

Vaz-Ferreira, R. (1976) Otaria flavescens (Shaw) South American sea lion. Advisory Commitee on Marine Resources Research. Scientific Consultation on Marine Mammals. Bergen, Norway. 48: 1-20.

Wickens, P.A. (1995) A review of operational interactions between pinnipeds and fisheries. FAO Fisheries Technical Paper: Rome, 346: 86.

Yodzis P. (2001) Must top predators be culled for the sake of fisheries? Trends in Ecology and Evolution 16(2): 78-84. 